\title{
"São velhas agonias, novas tecnologias" processos criativos e produtivos em meio à canção no cururu paulista
}

Elisângela de Jesus Santos ${ }^{1}$

Resumo

O artigo em questão dedica-se ao universo do cururu como canção tradicional paulista. $\mathrm{O}$ enfoque não está em analisar internamente o caráter formal da canção no cururu, mas sim em perceber os contextos históricos que a envolvem e as especificidades das relações marcantes da racionalidade que conduziu a forma do cururu para um tipo específico de canção popular. $\mathrm{O}$ texto aciona relatos orais dos realizadores e apontamentos de trabalho de campo para: a) compreender as dinâmicas organizadas por cantadores e violeiros em diálogo com outras linguagens e meios de difusão artística - circo, rádio, cinema e música sertaneja no estilo das duplas; b) observar o importante papel destes agentes na condução da totalidade dos processos e na difusão do cururu. Atenta-se ainda para o sentido da produção cururueira enquanto parte integrante da cosmovisão caipira e seu alcance no contexto musical contemporâneo, com destaque para o rap em São Paulo.

\section{Palavras-chaves}

Cururu do Médio Tietê paulista, cururu-canção, cosmovisão caipira, crônicas urbanas, rap, etnografia.

Recebido em 28 de março de 2014

Aprovado em 29 de agosto de 2014

SANTOS, Elisângela de Jesus. "São velhas agonias, novas tecnologias": processos criativos e produtivos em meio à canção no cururu paulista. Revista do Instituto de Estudos Brasileiros, Brasil, n. 59, p. 229260, dez. 2014. DOI: http://dx.doi.org/10.11606/issn.2316-901X.v0i59p229-260

1 Centro Federal de Educação Tecnológica Celso Suckow da Fonseca (CEFET, Rio de Janeiro, RJ, Brasil). 


\title{
"Old Agonies, New Technologies" Creative and Productive Song-related Processes in Cururu Paulista
}

\author{
Elisângela de Jesus Santos
}

\begin{abstract}
This article addresses the universe of cururu as traditional Paulista song, not by analysing its formal aspects, but noticing the historical contexts surrounding it and the specificities of the remarkable rationality relationships that shaped cururu into a particular type of folk song. Through oral accounts and fieldwork notes, the aim is to: a) understand the dynamics organised by cururueiros (ten-strings Brazilian guitar players who could be considered something between folk singers and troubadours) in dialogue with other languages and means of artistic diffusion - such as radio and cinema; b) observe the important role of these agents in these processes and the diffusion of cururu. Heed is taken to the meaning of cururu production as part of the caipira worldview and its reach in the contemporary music context.
\end{abstract}

Keywords

Cururu paulista, cururu-song, caipira cosmovision, urban chronicles, rap, etnografy. 


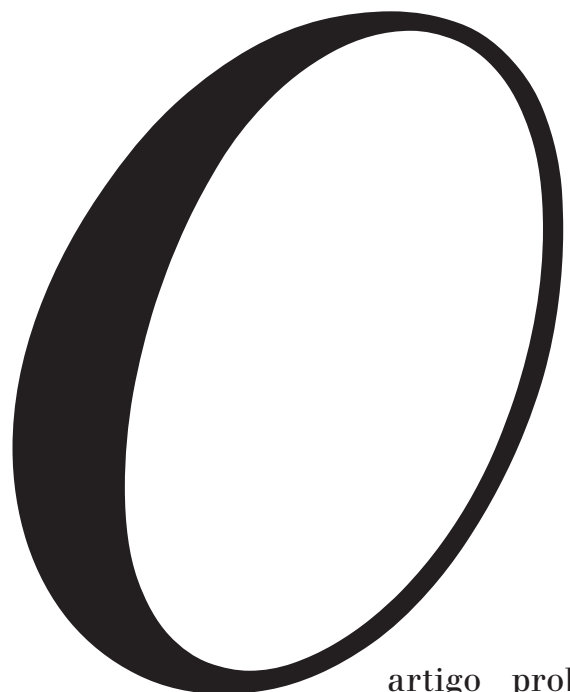

Nota introdutória

artigo problematiza aspectos relevantes da canção popular brasileira de matriz tradicional mas não pretende realizar uma observação analítica do ponto de vista musical. Quer antes, partir do universo que permeia e constitui o cururu do Médio Tietê paulista com enfoque na forma cururu-canção ${ }^{2}$ para apontar a contemporaneidade desta modalidade de canto popular-poético no improviso (repente paulista) conduzido por cantadores em debate verbal com mediação e acompanhamento sonoro da viola caipira.

O cururu constitui uma prática sonora - poesia oralizada e musicada na forma de improviso - que atribui aos realizadores um caráter de cancionistas $^{3}$. Esses cancionistas-cururueiros conduzem a fala cantada

2 IKEDA, Alberto T. Cururu: resistência e adaptação de uma modalidade musical da cultura tradicional paulista. In: ArteUnesp. Vol. 6, São Paulo, 1990.

3 Para o entendimento da canção como articulação do acompanhamento melódico (viola) em conjunto ao canto falado: TINHOR ̃̃O, José Ramos. História Social da Música Popular Brasileira. São Paulo: Editora 34, 1998. TATIT, Luiz. O Cancionista: composição de canções no Brasil. São Paulo: Edusp, 2002. Além de observarmos o cururu-canção atentando para a aliança entre melodia e poesia, parece-nos adequado aproximar a definição de 'cancionista' para os cururueiros do Médio Tietê quando articulada ao caráter de malabarismo empregada por Luiz Tatit ao definir o compositor de canções no Brasil. Atuando como mediador da linearidade do texto oralizado (ou de fala cantada) com a linearidade melódica, essa capacidade de mediação/articulação permeia uma especificidade do ser cururueiro: aquele que no plano prático e simbólico manipula a palavra para aproximar e separar dimensões opostas: celestes/terrestres, positivas/negativas, sagradas/profanas. SANTOS, Elisângela. Entre Improvisos e Desafios: do cururu como cosmovisão de grupos caipiras no Médio Tietê, SP. 201z. Tese (Doutorado em Ciências Sociais) Faculdade de Ciências e Letras, Universidade Estadual Paulista "Júlio de Mesquita Filho" - UNESP Araraquara, 2013. Para compreensão de como tais sonoridades 
em acompanhamento da viola ao fundo e/ou ainda intercalando silêncios da voz para que o instrumentista-violeiro possa trazer à tona a sonoridade da viola e abrilhantar os temas cantados ${ }^{4}$.

Como legado de ruralidade para a população que o realiza nas periferias de cidades como Piracicaba, Sorocaba, Votorantim, Botucatu, Tatuí, Tietê, Porto Feliz entre outras, o cururu é importante também para o conjunto da produção da canção muito em decorrência do caráter de crônica que os improvisos comportam. Isto pode ser percebido com mais ênfase a partir dos anos 1920 e 1930 pois, o caráter contemporâneo do cururu está articulado à forma espetáculo, resultante da adaptação dos cururueiros ao uso do microfone e amplificação da viola numa dimensão de palco ${ }^{5}$, bem como ao tratamento de temas atrelados ao cotidiano das relações:

Agora vai a rima do Sagrado/Este é o começo da função/Lembrando gente dos antepassado/E quero a vós esclarecê/Que na margem do rio Tietê/Que o Cururu foi disventado/Êi/eu ainda era menino/ Mas era muito inclinado/Quando vi o primeiro cururu/Eu levei de causo pensado/Eu aprendi cantá repente/Aqui dentro do meu estado/E pra mostrá quem é que eu sô/E dá um coro nos cantado/ todos cantadô famado/Hoje eu tô cantando verso/E mesmo com os tempo cansado/Sabe, cidadão não é de hoje/Que'u estou vivendo neste estado/Foi mil novecento e quatorze/Que'u fui nascido e também fui registrado/Meu nome é Pedro Francisco Prudente/ Canto verso no repente/Pra quarquer dum magistrado ${ }^{6}$.

Por conta dessas percepções o texto realiza dois movimentos. Um deles está relacionado a apontamentos etnográficos e relatos orais de realizadores de cururu da atualidade destacando o protagonismo de Nhô Serra e Pedro Chiquito na indústria fonográfica e na composição dos "Quatro Bambas" para entender meandros desses processos no início do século XX. O outro movimento tangencia a influência da prática e do imaginário cururueiros na produção musical da São Paulo

rituais e de cunho identitário desembocam na canção do século XX: TATIT, Luiz. O século da canção. São Paulo, Ateliê Editorial, 2004, além da já referida obra de José Ramos Tinhorão.

4. SANTOS, Elisângela. Entre Improvisos e Desafios.

5 IKEDA, Alberto T. Cururu: resistência e adaptação de uma modalidade musical da cultura tradicional paulista.

6 Pedro Chiquito, cantoria de improviso, rima do Sagrado. Trecho. CD Pedro Chiquito e Nhô Serra, s/d. 
contemporânea pensando a crônica (ou a dimensão dos causos muito presente no mundo rural-caipira-cururueiro) como uma especificidade cancional que conversa com o samba de favela dos anos 1960-70 e desemboca na atual cena rap paulistana.

\section{Somos reis, $\operatorname{mano}^{7}$}

Um paralelo deste verso de rap com a lógica do universo cururueiro está no uso de temas retirados de passagens bíblicas nas composições improvisadas. "Levanta e Anda" é frase emblemática das passagens dos Evangelhos de Marcos (2,1-12) e Lucas, (5, 17-26). Outra menção à Bíblia também pode ser ouvida na voz de Mano Brown em "Capítulo 4, Versículo 3" e na faixa "Diário de Um Detento" (Jocenir, Mano Brown), versos que compõem o disco Sobrevivendo no Inferno (1997). Num pouso do Divino ocorrido em 2010 na cidade de Anhembi, o cururueiro Manezinho Moreira cantou:

Falando de Jesus Cristo/do nosso Jesus menino Quando ele fugiu pro Egito/pai e mãe vinham seguindo Ia lá Santa Maria/tinha lá Santa Maria, Tinha um ladrão residindo (refrão) Lá, Santa Maria tinha uns ladrão residindo

Quando eles lá chegaram/a chuva tava caindo Depressa veio o ladrão/ ele vê o assassino Ameaçando São José/por ser um home de fé/E Maria e o menino

Mas atrás chegava Dimas/ veio por ser ladino, Então Dimas disse pra Jessica/desse jeito eu não combino Respeitando o juramento/ e você não tá cumprindo O juramento que fizemos/você não tá corrigindo $\mathrm{O}$ juramento foi com fé/ que respeitar velho e mulher/E as crianças pequenino/Respeitar o velho e mulher e as crianças pequenino

$[\ldots]$

Então vinha Herode/ e a escolta vinha vindo

7 Verso de "Levanta e Anda", do álbum de Emicida "O Glorioso Retorno de quem nunca esteve aqui" (Laboratório Fantasma, 2013). 
Chegô na frente do castelo/ aquele soldado assassino

Então Dimas saiu na porta/rancou o punhal damastino

O brilho desse punhal/fez a escolta voltar

E salvou a vida do menino/Fez a escolta vortá/salvô a vida [gritos e aplausos da plateia]

Quando foi o dia cedo/ que José foi despedindo

Dimas carregou Jesus/Dimas carregou o menino

Uma criança tão pequeno/ e assim foi dirigindo

A verdade digo hoje/verdade eu digo hoje/Foi a palavra do menino

"Você morrerá comigo/ quando tudo for tranquilo"

Com 33 ano de idade/foi que morreu Jesus menino. ${ }^{8}$

Os ciclos de prestígio que implicam a lógica cururueira podem ser lidos sob diversos pontos de vista. Um deles está expresso na autodenominação do grupo que acompanhamos durante nossos trabalhos etnográficos em Sorocaba e Votorantim. Em conjunto, são eles "Os Reis do Cururu". A questão da autodenominação é interessante no meio cururueiro e resulta em diversas alcunhas. No plano individual, nomes como "Bigode de ouro", "Diamante Negro", "Canário da Terra", "Peito de aço" são comuns no universo cururueiro, assim como acontece na cena hip hop: um mesmo rapper pode contar com várias (auto)denominações como é o caso de Marcelo D2 também "Sinistro", "Cascudo", Sinônimo de Subversão" e Emicida também autoreferido como "Zica". 9

Curioso é atentar para a relação intrínseca entre os versos cantados por Adriana Drê que remetem à cena hip hop em "Bang!": “quem é quem nessa multidão/ei, olhe ao seu redor, camarada/pra que

8 Transcrição nossa. Anhembi, 2010. Jonata Neto e Manezinho Moreira cantam em pouso do Divino trecho da ida de Jesus e sua família para o Egito. O trecho cantado por Manezinho e aqui transcrito remente ao seguinte texto bíblico: "A fuga para o Egito. Depois da partida deles, eis que o Anjo do Senhor aparece em sonho a José e lhe diz: "Levanta-te, toma contigo o menino e sua mãe, e foge para o Egito; fica ali até a nova ordem, pois Herodes vai procurar o menino para fazê-lo perecer”. José levantou-se, tomou consigo o menino e sua mãe, de noite, e retirou-se para o Egito. Ali ficou até a morte de Herodes, para que se cumprisse o que dissera o Senhor pelo profeta: Do Egito chamei meu filho (MATEUS, 2, 13-15).

9 Marcelo D2 registra essa sequência de alcunhas em várias de suas gravações e Emicida o faz em "Bang!" pautada pelo refrão de Adriana Drê. O termo que aponta para a ambivalência e realiza conversão da conotação negativa pode ser lido na faixa "Zica", vai lá do álbum Doozicabraba e a Revolução Silenciosa, 2011 e no título do disco de 201z: O Glorioso Retorno de quem nunca esteve aqui. 
as trevas não levem seu brilho/pra que as coisas não saiam do trilho/ em todo momento, atenção/ei, olhe ao seu redor camarada". Emicida na sequência, arremata: "neguinho o caralho, meu nome é Emicida, porra/ou Zica". ${ }^{10}$ A própria denominação Emicida consiste numa sigla: "Enquanto Minha Imaginação Compõe Insanidades Domino a Arte".

O cururu comporta um caráter de transformação de sua forma estética que dificulta o enquadramento num esquema conceitual fixo ${ }^{11}$. Por ser uma cantoria de improviso, a prática vincula-se ao universo da oralidade e registros escritos não são consensuais acerca de suas efetivas origens e transformações no tempo ${ }^{12}$.

A elaboração realizada pelo etnomusicólogo Alberto Ikeda é indicativa das possíveis transformações pelas quais o cururu teria passado desde suas remotas origens:

1) danças cerimoniais indígenas; 2) reinterpretação das danças cerimoniais indígenas; 3) cururu-dança: dançado em roda, diante dos altares, com temática predominantemente religiosa e com canto improvisado (desafio implícito) comum no ambiente rural; 4) cururu cantoria de improviso, sem dança, com temática profana (desafio explícito); 5) cururu-canção: gênero de canção sertaneja, com permanência apenas do ritmo tradicional. ${ }^{13}$

10 Em citação que faz referência direta ao personagem "Dadinho" do livro Cidade de Deus e filme homônimo: "Dadinho é o caralho, meu nome agora é Zé Pequeno, porra”. Interessante que o diálogo com o audiovisual nesta música está na citação a este filme, mas também no vídeo que ilustra "Bang!" onde há uma articulação proposital entre o verso do refrão: “quem é quem nessa multidão" e a imagem de uma construção urbana com a pichação "hip hop" em explícita menção à cena musical de onde provém Emicida. Aliás, toda a produção de "O Glorioso Retorno" flerta com videoclips e está permeada por imagens que buscam sintetizar cada uma das faixas e documentar o álbum, compondo um produto visual que complementa o produto sonoro quando realiza uma metalinguagem dos encontros durante a produção e gravação das canções e do texto "Milionário do Sonho" de Elisa Lucinda.

11 Assim, quando tratamos do cururu como sonoridade tradicional limitamos sua definição enquanto canção: é elástico dado a variações de temas e ritmos entendendo que seu caráter de improviso não invalida sua constituição enquanto canção. TATIT, Luiz. O século da canção e TINHORÃO, José Ramos. História Social da Música Popular Brasileira.

12 ARAÚJO, Alceu Maynard. Folclore Nacional II: danças, recreação e música: São Paulo: Martins Fontes, 2004 [Coleção Raízes]. p. 83-4; CANDIDO, Antonio. Possíveis raízes indígenas de uma dança popular. Revista de Antropologia. São Paulo, 1956.

13 IKEDA, Alberto T. Cururu: resistência e adaptação de uma modalidade musical da cultura tradicional paulista, p. 49. Grifo nosso. Ainda que o autor em questão trate do cururu-canção em relação ao ritmo, observamos que o caráter de causos e temáticas narrativas do cururu do Médio Tietê também dialoga com a produção sonora brasileira contemporânea. 
Passando por modificações estéticas até alcançar a forma canção, o cururu não perdeu o sentido de experiência sonora coletiva. Podemos literalmente dizer que ela foi amplificada. Respondendo aos processos históricos de êxodo rural, migração e de reconfiguração da paisagem rural, o cururu é estética que em muito se diferencia das formas de arte pautadas na individuação para fins de sucesso profissional e comercial de amplo alcance midiático.

Como desafio explícito, sem dança e com temática profana como entende Alberto Ikeda e enquanto objeto de consumo cultural inserido na lógica de mercado, o cururu manteve sua constituição rítmica e melódica $^{14}$. Ainda que tenha acompanhado os processos de registro sonoro e de enquadramento técnico para o mercado consumidor, adequandose também à forma espetáculo em palcos urbanos, a gravação isolada que caracteriza o cururu-canção não pode apreender a totalidade do cururu no contexto de sociabilidade em que ele é produzido. Ainda que a gravação resulte na representação de um dado modo de vida ou prática identitária e de sociabilidade, o exercício cotidiano da prática e da memória cururueira constitui a própria vivência do canto rimado no improviso e do som da viola.

Mesmo que a gravação autoral de cururu-canção seja expressiva da vida e dos elementos da identidade cururueira, não é a exibição ou execução isolada que garante a permanência de seus sentidos. E isso se justifica à medida que a dimensão do encontro e da vivência da sociabilidade e das relações de compadrio (parentesco por afinidade), mutirão e parcerias vividas no cotidiano resultam numa linguagem específica (o próprio cururu) que é tanto uma forma de produção cultural quanto a expressão de uma cosmovisão caipira.

Guardadas as devidas proporções, podemos aproximar o universo cancional do cururu às propostas do álbum "O Glorioso Retorno de Quem Nunca Esteve Aqui" de Emicida ${ }^{15}$. Na cena hip hop, tal como no cururu, fala-se e faz-se música no presente em diálogo constante com o passado. É o que se pode ouvir na faixa "Gueto", onde há menções explícitas ao rapper como contador de causos que busca lugar junto aos afamados cronistas

14. IKEDA, Alberto T. Cururu: resistência e adaptação de uma modalidade musical da cultura tradicional paulista.; Folias de Reis: sambas do povo. São José dos Campos: Fundação Cassiano Ricardo/Centro de Estudos da Cultura Popular, 2oı; SANTA ROSA, Sérgio. Prosa de Cantador: a história e as histórias dos cururueiros paulistas. São Paulo: Fepaf, 2007.

15 Laboratório Fantasma, 201z. Para ouvir e ver o álbum: https:/www.youtube.com/ watch?v=Oe6dpYScIKE. Para uma leitura faixa-a-faixa: http://farofafa.cartacapital. com.br/2013/og/o6/reforma-agraria-na-mpb/. Acessos em: 28 ago. 2014 . 
do passado: "a pampa de tanta fofoca/tamo na rua/dando salve/pique Adoniram/saudosa maloca". Uma variante de "tamo na rua" é "a rua é nóiz". Já em "Hino Vira-Lata” há metalinguagem: a música reúne um conjunto de vozes masculinas em coro uníssono com o chamamento, intervenção e mediação do rapper e em meio a palmas e arranjos de solo. A dimensão da música como encontro e realização coletiva é auto-realização situada no presente vivido. A variante está explícita no texto poético que intercala a gravação das faixas "Bang!" e "Gueto": "O que quero pra mim quero pra todo o universo: é esse o papo do meu verso". ${ }^{16}$

Essa noção está associada à ideia de que a produção individual permeia um dom natural e divino referendada pelo hino como canção de louvor cantado por todos em mutirão uníssono: daí a presença do Quinteto em Branco e Preto. A faixa é expressiva da música contemporânea como parte da memória e de legado herdado por gerações anteriores, sobretudo da tradição de contação de causos. Não por acaso, "Hino Vira-Lata" começa em uníssono: "Meu coração/tá na mão/do ritmista/ do $D j /$ no pandeiro do repentista" e o vídeo que ilustra a produção da canção e do encontro traz Emicida mostrando LPs gravados por grandes nomes do samba e da música popular influenciada por ritmos e sonoridades tradicionais, forjadas no meio rural ou nas periferias e favelas das cidades. Toda essa composição está sintetizada no título da faixa: "Vira-Lata" é também o "Malandro" no contexto urbano carioca que a música refere como "Maloqueiro", termo mais atrelado ao contexto paulista de Adoniram: saudosa maloca ${ }^{17}$.

A operação de conversão de ideias faladas em soluções cantadas, cuja métrica coloquial ${ }^{18}$ independe das métricas poéticas escritas ${ }^{19}$,

16 Elisa Lucinda em verso de "Milionário do Sonho" lido com Emicida para integrar as faixas do referido disco.

17 Aqui há uma conversa entre diferentes faixas do mesmo disco: "Hino Vira-Lata", "Bang!" e "Gueto", acenando novamente para o papel individual do rapper na cena como um todo - movimento que ocorre em vários momentos do álbum.

18 O esquema métrico mais comum no cururu é A-B-A-B-A-B-C-C-B para a estrofe de nove versos e a classificação dos versos quanto às rimas é verso trovado: A-BC-B-D-B (rima simples) ou A-B-A-B-A-B (alternadas); verso dobrado com rimas interpoladas, tipo A-B-B-A-C-C-A. Entende-se por dobra a repetição, no verso que segue, do som final do verso anterior. Há também o verso tresdobrado, atribuído no meio ao cantador Zico Moreira, cujo esquema A-B-B-B-A-C-C-A indica a trova dobrada duas ou três vezes. Dentre as carreiras mais utilizadas estão as do A, Sagrado, São João, Divino. As terminações como ino (Divino), vai-e-vem, São Bento, Santa Teresa, Santa Catarina, São Vicente, Virgem Pura e outras menos usuais, como Presumido (ou preso e unido a Jesus Cristo) são consideradas carreiras "duras", termo usado pelos cururueiros para definir os versos com terminações mais difíceis de compor.

19 TATIT, Luiz. O século da canção, p. 156. 
estando mais articulada ao ritmo sonoro (inclusive corpóreo, ou intuitivo, da voz humana) dos acompanhamentos, é o que define nosso entendimento do cururu na forma cancional. Tal sonoridade é obtida através da própria voz do cantador (em vocalizes introdutórios ou vinhetas) e através da viola caipira (instrumento insubstituível). Também pode haver junção de elementos percussivos como pandeiro e reco-reco, além de outros instrumentos de cordas como baixo elétrico e o violão. Ocasionalmente podem ser vistos instrumentos de teclas (acordeão) na composição da sonoridade cururueira paulista.

Julieta de Andrade ${ }^{20}$ observa que o cururu "é uma literatura poético-musical em linguagem do quotidiano que se apresenta como um dialeto literário não-formal da língua falada no Brasil":

Cada cururu é uma sessão poético-musical - excepcionalmente coreográfico-poético-musical - com duração média de cinco horas [...] e consta de uma série de poemas cantados por quatro trovadores sendo dois contra dois: primeiro e terceiro porfiam contra segundo e quarto. Eles cantam por rodadas sucessivas, chamando-se carreira cada série de apresentações. Carreira ou linhação é a rima obrigatória de cada ato. Cada cururu apresenta de quatro a sete carreiras. Linha tem o significado de verso ${ }^{21}$.

A dinâmica de reconhecimentos desdobra-se numa lógica prestigiosa: se não existe cantador sem violeiro, um cantador afamado "puxa" para si um bom violeiro e os dois juntos "puxam" uma boa assistência. Quanto maior for a presença de cururueiros afamados ou tarimbados numa dada ocasião, maior a chance de haver "cururu bão" e maior a

20 ANDRADE, Julieta Jesuína Alves de. Cururu: espetáculo de teatro não-formal poético-musical e coreográfico. 1992. 3 vl. Tese (Doutorado em Artes) - Escola de Comunicações e Artes, Universidade de São Paulo, USP. São Paulo, 1992.

21 ANDRADE, Julieta Jesuína Alves de. Cururu, p. 31. A duração média dos encontros de cururus mensais que acompanhamos em trabalho de campo é de cinco horas. As rodas mensais têm início previsto por volta das 19 horas a cada primeiro sábado do mês no Rio Acima, no município de Votorantim e no último domingo, às 17 horas no Clube Atlético Barcelona de Sorocaba. E há programas de cururu transmitidos via rádio em emissoras da região. Em Sorocaba, a Rádio Cacique transmite o cururu todos os domingos a partir das 6 da manhã. Durante muitos anos, o programa de cururu da Cacique foi comandado por Darcy Reis já falecido. Em Porto Feliz o cururu divide espaço com a programação sertaneja da Rádio Nova Porto em programa comandado pelo radialista e apresentador de cururus e show sertanejos, João Carlos Martinez. Em Piracicaba, o comando é de Moacir Siqueira na Rádio Difusora. 
motivação da assistência para acompanhar os desafios e consumir as gravações.

Propondo ainda algumas aproximações da lógica cururueira com a cena hip hop para pensar em outra das especificidades da produção do disco já mencionado, percebemos que são diversas as parcerias da voz principal com as vozes e presenças de outros artistas e da família do $M C$ (Pitty, Fabiana Cozza, Tulipa Ruiz, Juçara Marçal, Rael, Projota, Quinteto em Branco e Preto, Guimê, Wilson das Neves, Elisa Lucinda, além da mãe Dona Jacira e a filha do rapper Leandro, entre outros).

"Hino Vira-Lata" parece-nos bem expressiva da noção de mutirão musical que permeia o universo cururueiro: "música é luz/que vem e faz/que é pra dividir com todos/igualzinho o sol faz". Mas esse mutirão não está apenas no verso de Emicida e no coro do Quinteto. É muito forte em Elisa Lucinda: "minha palavra não sou só eu/ minha palavra é a cidade/Mundão redondo, Capão Redondo/Coração redondo na ciranda da solidariedade. A rua é nóiz cupadi". ${ }^{22}$

Sabemos da importância histórica e simbólica do mutirão para a construção das casas de famílias empobrecidas, bem como do amparo da vizinhança nos momentos de necessidade. Essa lógica remete ao mundo rural e ao universo caipira e, com os processos de êxodo rural e migração, foram ressignificados nas periferias de São Paulo ${ }^{23}$ e nas favelas cariocas. Como aponta o drama da família do rapper narrado pela própria dona Jacira: "Seu Zé é a representação do Estado no Jardim Fontalis, talvez até hoje”.

A dimensão prestigiosa é inerente ao cururu. Por meio dele, alguém antes anônimo pode vir a se destacar recebendo constantes convites para compor as rodas e atuar em outras instâncias coletivas, para além da dimensão artístico-cultural. A todo aquele que se realiza no cururu implica ação social que impacta no plano cotidiano das relações humanas.

A capacidade artística para exercer o dom de cantar cururu ou de tocar a viola faz com que o cantador ou o violeiro adquiram um status social diferenciado, indissolúvel da noção de prestígio. Esse prestígio tem duas dimensões, uma celeste (dom do Espírito Santo ou dom do Divino) e outra, terrena. Ainda que associada ao plano religioso essa primeira

22 Milionário do Sonho, texto de Elisa Lucinda. Trecho.

23 SANTOS, Elisângela. Entre Improvisos e Desafios. "Levanta e Anda" é, no álbum glorioso, a narrativa sonora testemunhal que atenta para dimensão de luta e privação de grupos empobrecidos na periferia de São Paulo. "Atividade pra dar continuidade nisso" está na faixa seguinte: "Nóiz". 
noção orienta a segunda e vice-versa, de modo que a produção cultural legitima a condição social dos realizadores.

Portanto, qualquer entendimento da produção musical no universo cururueiro não pode negligenciar esses atributos de dom, tarimba e fundamento formando diversas parcerias que constituem o legado da prática $^{24}$. Na cena paulista e para o caso específico ao qual nos debruçamos, tanto em "Bang!" quanto em "Hino Vira-Lata”, o rapper tal qual um repentista é portador um legado musical e civilizatório ${ }^{25}$ :

É o que eu digo e faço, não suponho: sou milionário do sonho [...]. Inventando o que somos, minha mão no jogo eu ponho, vivo do que componho, sou milionário do sonho. Vou tirar onda, peguei no rabo da palavra e fui com ela, peguei na cauda da estrela dela. A palavra abre portas, cê tem noção? É por isso que educação, você sabe: é a palavra-chave. É como um homem nu todo vestido por dentro, é como um soldado da paz armado de pensamentos, é como uma saída, um portal, um instrumento. No tapete da palavra chego rápido, falado, proferido na velocidade do vento, escute meus argumentos. São palavras de ouro, mas são palavras de rua. Fique atento. [...]. Minha nave é a palavra, é potente o meu veículo sem código de barra, não tem etiqueta embora sua marca seja boa, minha alma é de boa marca, por isso não tem placa, tabuleta, inscrição. Meu cavalo pega geral, é Pegasus, é genial. A palavra tem mil cavalos quando eu falo. Sou embaixador da rua, não esqueço os esquecidos e eles se lembram de mim $^{26}$.

Para cantadores de cururu que fizeram adaptações na forma estética com fins de registrar sua obra nos anos 1940-50, a gravação sonora de um disco em 78 rpm está mais ligada à reprodução do prestígio e ao reconhecimento social no meio cururueiro do que propriamente à

24. Nem todo mundo que tá é, nem todo mundo que é tá”. Essa ideia finaliza os últimos versos de "Bang!", do referido "Glorioso" de Emicida e dialoga exatamente com a exigência de dons/tarimba/fundamento como legitimação para o efetivo pertencimento de uma dada cena musical (meio ou roda) tanto como militância, no caso do hip hop ou de liderança identitária, no caso do cururu. Em ambos os casos, está implícita a questão do reconhecimento e prestígio interno ao grupo, independentemente do reconhecimento exterior: afinal o retorno é glorioso, mas trata-se de alguém que nunca esteve aqui.

25 O cururueiro é um educador da plateia, ele educa "pela" e através da palavra. A noção é válida para aproximá-lo do papel do professor ou evangelizador, aquele que professa um sermão. Sobre isto: SANTOS, Elisângela. Entre Improvisos e Desafios.

26 Milionário do Sonho, Elisa Lucinda. Trecho. Transcrição nossa. 
necessidade de reconhecimento econômico e projeção artística para o sucesso comercial.

Orientação semelhante tinham os primeiros sambistas cariocas no início do século XX: a gravação fonográfica das produções representava antes um encontro com sua própria identidade ${ }^{27}$, marcada pela migração do norte-nordeste para o sudeste - tal como no êxodo rural no contexto cururueiro paulista. Mais do que a necessidade de se encaixar em padrões impostos por uma lógica econômica alheia às suas visões de mundo, os artistas populares em questão estão engajados em mutirões materiais e simbólicos na luta pela expressão dessas (mesmas) visões de mundo que portam - e onde são forjados.

Tais mutirões são constituídos por momentos em que a coletividade se reúne num debate poético composto por temas que cercam suas alegrias e angústias cotidianas, e portanto, permeiam seu existir histórico (rodas de cururu, rodas de samba do "Povo da Colina", ${ }^{28}$ rinhas de rap). Esse sentido perpassa os séculos XX e XXI na São Paulo do Médio Tietê paulista, nas periferias paulistas e favelas cariocas.

A noção de composição coletiva que extrapola a lógica comercial marca a trajetória de compositores e intérpretes de renome como José Bezerra da Silva (1927-2005). Não por acaso, o disco de estreia de Bezerra, O Rei do Côco, é ilustrativo de sua particular aptidão para as rimas improvisadas. Lançado em dois volumes, os discos de 1975 (vol. 1) e 1976 (vol. 2), sintetizam sua faceta de percussionista e de compositor dos repentes tradicionais nordestinos:

A rima seguida do meu repente/ela é de doer/Eu dou razão a quem não souber dizer/ Porque/é que a rima seguida desse meu repente/ ela é de doer/Eu dou razão/a quem não souber dizer/O meu repente é plenamente consciente/Ele é decente/e tá na linha de frente/É exigente, impertinente e renitente/Você veja o que acontece/a quem tentar dizer o meu repente [...] Se o sujeito tentar dizer o meu repente/Dá dor de dente, nevralgia e congestão/Dói o pulmão, o coração, o cotovelo/Ele ainda consome a mente/e também quebra queixo e tornozelo ${ }^{29}$.

27 TATIT, Luiz. O século da canção, p. 34.

28 "Povo da Colina" é composição de Walmir da Purificação, Tião Miranda e Roxinho, décima faixa do disco Violência Gera Violência (RCA/BMG, 1998) de Bezerra da Silva.

29 Transcrição de "Rima de Doê" composta por José Bezerra da Silva (1927-2005) e gravada no álbum "O Rei do Cóco", (Tapecar, 1975, vol. 1). Acerca de Bezerra como artista de projeção nacional estigmatizado como "cantor de bandido" ou dos "que 
A título de registro e em relação as articulações atuais entre cururu-samba-rap como narrativas cancionais com pontos comuns, Marcelo D2 propõe fusão explícita entre rap e samba em "Meu Samba é Assim" de 2006 e com citações de versos de samba contemporâneos

e "das antigas" sampleados em várias composições. O rapper gravou o disco "Marcelo D2 canta Bezerra da Silva" (EMI Music, 2010) revisitando as composições gravadas por Bezerra e relendo a capa de "Eu Não Sou Santo" gravado por Bezerra em 1990 pela BMG-Ariola.

\section{Bambas, bamba: MCs são griots $^{30}$}

Manezinho Moreira é neto de catireiro e foi iniciado na arte da viola ainda na infância. Sua trajetória no cururu é permeada pelo instrumento. Na atualidade, Manezinho é cantador que durante a mocidade tocou para cururueiros renomados como Nhô Serra e Pedro Chiquito, integrantes do que ficou conhecido como os "Quatro Bambas do Cururu", grupo composto primeiramente por Sebastião Roque, João Davi, Zico Moreira e Dito Silva ${ }^{31}$.

Posteriormente e com a morte de Bastião Roque, Dito Silva e João Davi - Zico Moreira faleceu em 2002 aos 101 anos - o grupo adquiriu nova formação com Pedro Chiquito, Parafuso e Nhô Serra ${ }^{32}$."Era preto

vivem à margem da lei" trata o documentário "Onde a coruja dorme" com roteiro e direção de Márcia Derraik e Simplício Neto. Produção: TV Zero e Antenna, 2012. Disponível em: https://www.youtube.com/watch?v=fSsoXıRPLuU Acesso em: 10 fev. 2014; VIANNA, Letícia C. R. Bezerra da Silva: produto do morro: trajetória e obra de um sambista que não é santo. Rio de Janeiro: Jorge Zahar, 1999.

zo A aproximação entre griots e MCs está em verso de "Ubuntu Fristaili", faixa do Glorioso. O termo "Bamba" é quase auto-referencial do universo sambista em várias citações: "Eu quero morrer/numa batucada de bamba/na cadência bonita do samba": "Na cadência do samba" (Paulo Gesta e Ataulfo Alves, 1962). A composição foi gravada por diferentes bambas desde Elizete Cardoso (1920-1990) e até Novos Bahianos em "Vamos pro Mundo" (Som Livre, 1974). O termo permeia também o universo jongueiro de Martinho da Vila em "Casa de Bamba" (RCA, Victor, 1969). Problematizar tal debate não cabe aqui, mas interessa a aproximação em termos de ambivalência: a condição prestigiosa é paralela à de humildade remetendo ainda ao que foi aqui dito sobre o termo "Zica" convertido em "Bamba". Essa visão de mundo ambivalente é preciosa no universo cururueiro. SANTOS, Elisângela. Entre Improvisos e Desafios.

31 SANTA ROSA, Sérgio. Prosa de Cantador: a história e as histórias dos cururueiros paulistas.

32 Oscar Francisco Silva Bueno, publicado em Cururu em Piracicaba, livro de Olivio N. Alleoni. Disponível em: http://memorial-piracicaba.blogspot.pt/20o8/12/ 
contra branco" diz Manezinho em depoimento para "Prosa de Cantador". O meio cururueiro não é majoritariamente composto por negros e é interessante que Manezinho defina os quatro bambas desta forma ${ }^{53}$. Manezinho foi observador atento das transformações pelas quais o cururu passou ao longo de mais de 50 anos. Uma das características que resultam na expressão de sua subjetividade teria sido, segundo ele relata, "uma forma de modernizar" o toque da viola no cururu inserindo floreios e ponteados.

Sérgio Santa Rosa, em Prosa de Cantador, afirma que o cururueiro Luizinho Rosa atribui a Dito Viola e Donizete o pioneirismo do novo estilo. Ao mesmo tempo, João Davi teria afirmado, em testemunho dos anos 1980, que o violeiro Pedro Canário era o responsável pela inovação. Como se percebe, a questão da autoria individual e sem registro formal é algo difícil de precisar em modalidades tradicionais de cantoria de cunho coletivo.

Num misto de denúncia e conformismo, temas complexos da vida social, tais como relações entre negros e brancos, adquirem a ambiguidade risonha das expressões sonoras e gestuais populares. Aciona-se o dom para brincar com as palavras compondo versos que ora mantém e ora invertem o ordenamento social:

É meu compadre e meu ermão/eu adoro este negrinho de todo o meu coração/É meu compadre quatro vez/e eu adoro este negrão/Mas uma coisa eu prometo/se vocês quer que eu surro o preto/ eu meto o coro no negrão/E agora está o Chiquito/com esse pandeiro na mão/Falaro qu'ele é preto/Luizinho não achô bom/não quer que o Chiquito seja preto/que chapéu o do tontão/ Veja que coisa de siste/pinta o preto que nem pixe/ele quer que seja alemão/ [risos] Quem é que não está vendo/que é preto este negrão?/ Porque a cor não vale nada/diga se é verdade ou não/ pode ser que seja preto/mas tenha um santo coração/E para o Cristo celestiá/ai preto e branco são iguá/E viva Deus no coração ${ }^{34}$.

sebastio-da-silva-bueno-nh-serra.html. Acesso em: 12 mar. 2013.

33 João Davi, Parafuso e Pedro Chiquito eram os cantadores negros que compuseram as formações dos "Quatro Bambas".

34 Nhô Serra contra Pedro Chiquito. Cantoria de improviso em Pouso do Divino em Tietê. Os dois são cururueiros afamados falecidos. Imagens de arquivo, composição de filme removido do youtube com transcrição da pesquisadora. Acesso em: 25 jan. 2013. 
No trecho, Nhô Serra, conhecido como "cururueiro de microfone", improvisa cantoria para o grande amigo e "ermão" Pedro Chiquito. Serra aciona relações afetuosas para resolver supostas questões da diferença e desigualdade que poderia haver entre os dois: são compadres e o cantador tem muita estima por Chiquito.

De maneira curiosa, ao expressar a condição diversa que os peculiariza, Serra anula a diferença entre brancos e negros ${ }^{35}$. E o faz através de um pressuposto de igualdade atribuído ao sagrado na figura do Cristo. Serra diz que os homens estão numa condição de inferioridade perante o Deus maior e querelas étnicos-raciais são diferenças notórias por que todos os presentes veem "que é preto este negrão". Mas a condição de negritude de Chiquito é afirmada para ser invisibilizada e sutilmente negativada no verso seguinte: "a cor não vale nada" já que "pode ser que seja preto/mas tenha um santo coração". Então antes de "ser preto" é melhor "ser bom". E Deus, como Pai, é então chamado para dar a benção ao final da sentença.

A piada não é apenas um passatempo lúdico manifesto através de uma história inocente: "A dor dos judeu choca/a nossa gera piada/ [...] Tira a favela/ela te mostra cinquenta tons de roxo", canta Emicida em "Bang!" A piada acaba por estimular de forma dissimulada o preconceito étnico-racial e outras formas de preconceito - contra mulheres, homossexuais, idosos, estrangeiros, deficientes e contra práticas religiosas específicas. "Ao provocar o riso, a piada dissimula e descontrai os possíveis conflitos e o mal-estar entre os emissores e os receptores da mensagem". ${ }^{36}$

35 O tema das relações entre negros e brancos é constante na música popular. Para os casos que nos interessam atentemos para a música sertaneja dita "raiz": em 1968 a dupla Jacó e Jacozinho gravou pela Continental o disco "Preto e Branco". A música que intitula o álbum tem composição assinada por Sulino (Francisco Gottardi, 1924-2005) e Moacyr dos Santos (1932-1996) e apresenta-se na forma "pagode", outro gênero prestigioso da música caipira. A letra aponta supostas diferenças/oposições civilizatórias entre brancos (que apreciam bebidas alcoólicas) e negros (que gostam de beber) e faz encaminhamentos semelhantes aos realizados por Nhô Serra na cantoria de improviso em desafio à Chiquito. Os sertanejos eram irmãos nascidos em Assis, interior de São Paulo e pertenciam a uma família de catireiros. Segundo algumas notas biográficas difundidas pela internet a dupla é aproximada à Tião Carreiro e Pardinho na vendagem de discos nos anos 1970. A nota biográfica que nos parece mais confiável neste sentido pode ser vista em: http://www. boamusicaricardinho.com/jacoejacozinho_36.htmlhttp://www.youtube.com/ watch?v=Dip_EaOGsTM\&feature=email. Acesso em: 12 mar. 2013.

36 FONSECA, Dagoberto José. Você conhece aquela? A piada, o riso e o racismo a brasileira. São Paulo: Selo Negro, 2012. A título de registro e sobre este aspecto, em O Glorioso Retorno de quem nunca esteve aqui, a faixa "Trepadeira" gerou 
Em resposta à fala de Nhô Serra, diz Pedro Chiquito:

Benedito era italiano/escuro que nem um carvão/e a sua irmã gêmias/tamém teve canonização/Respetivo cor de homem/ tancava isso na nação/Ele tem sangue de escravocrata/ eu já vi pela feição/Eh, então você tenha sossego/que foi os braço foi daqueles velho negro/ [ele salta como enfatizando] que levantô esta nação/ [aplausos e gritos]. Foi o braço da negrada que levantô esta nação/Foro lutando e foi sofrendo/e aguentando escravidão/Mas atrás veio italiano/e pra negrada deu a mão/ Daí o Brasil levanto/que o Brasil tava no chão/Ei, largue mão de ser maroto/arrespeite o trabalho dos outro/dentro da sua nação/O preconceito de raça/entro da Constituição/tem cuidado meu amigo/senão taco ocê na prisão/Tem preconceito de raça/e de nome de religião/Temo num país de liberdade/aprovo pra quarqué cristão/É só que falar verdade/que não quer mais liberdade/que fique na prisão. ${ }^{37}$

Chiquito é conhecido como "cururueiro historiador". Seu estilo de cantar temas "históricos" e profanos faz com que resolva a peleja "respetivo a cor de homem" não tanto acionando um Deus conciliador, mas evocando uma aproximação entre sagrado e profano, através da figura do "Santo dos Preto", tal como faz Elisa Lucinda depois que o fim do mundo acaba em samba: "por isso eu digo e repito: quem quiser ser bom juiz, deve aprender com o preto Benedito". ${ }^{38}$

E tal como Nhô Serra, Chiquito aciona noções de igualdade. Mas sua versão está pautada na concretude das relações sociais sem sobrepô-las ao plano celeste. Trabalhador negro-africano e Beneditosanto-italiano-dos-preto estão ligados e quase podem os dois ser vistos como Pretos Velhos: Benedito "deu o braço pra negrada" e foi também o

diversas críticas por parte de setores dos movimentos de mulheres à narrativa do rapper que contou com a participação de Wilson das Neves. Na tentativa de responder às críticas, Emicida publicou nota sobre o episódio em sua página nas redes sociais. Disponível em: https://www.facebook.com/EmicidaOficial/ posts/568493269875016. Acesso em: 23 ago. 2014. Outro texto que trata da polêmica pode ser visto em: http://arvoresdenatal.wordpress.com/2013/o8/23/o-desamor-acritica-e-o-sansevieria/. Acesso em: 23 ago. 2014.

37 Pedro Chiquito responde Nhô Serra em Pouso do Divino em Tietê, imagens de arquivo, composição de filme com imagens de arquivo removido do youtube. Acesso em: 25 jan. 2013. Transcrição e grifos nossos.

38 Milionário do Sonho, texto de Elisa Lucinda. Trecho. 
juiz de Lucinda. E aqui Chiquito cria imagem de aliança cor/pórea entre celeste e terrestre, ressaltando a diferença entre brancos e negros por meio do cor/po. Chiquito tem São Benedito como referência de devoção, mas também reconhece a importância da população negra trabalhadora.

Como negro, Chiquito assume o discurso que reafirma a negritude, inclusive batendo o pé no tablado que o sustenta dizendo com voz e corpo enfáticos durante a performance que foram seus antepassados grandes responsáveis pela condição material de toda uma nação. A condição de trabalhador que ascende socialmente por meio do trabalho assalariado ou na lavoura é seguramente um dos estatutos mais valorizados no cururu. O indivíduo como trabalhador seja em prol do cururu, seja para sustentar sua família é digno de muito reconhecimento social.

Cururueiro da atualidade, Cido Garoto fala sobre o empenho de Nhô Serra em difundir o cururu pelo Brasil. Nhô Serra tornou-se empresário do cururu à medida que ia promovendo alguns cantadores, ou seja, ia adquirindo prestígio à medida que o ofertava ${ }^{39}$. Mais do que companheiros nas cantorias de cururu, Chiquito e Serra mantiveram uma amizade de longa data e eram parentes por afinidade. A estreita relação de compadrio mantida na parceria dos cantadores, inclusive durante os 1950 e 1960 já em contato com a indústria fonográfica, marca os registros de biografia e obra dos dois cururueiros ${ }^{40}$.

A inserção de cururueiros na música comercial foi evidenciada pela atuação de Cornélio Pires (1884-1958) no final da década de 1920. Em 1929, o folclorista reúne duplas em estúdio na capital paulista e em maio do mesmo ano lança cinco produções custeadas com dinheiro e selo próprios, além de compor a produção com numeração exclusiva veiculada pela Columbia.

As gravações em 78 rpm lançadas por Pires totalizam 48 discos de música caipira lançada como música comercial de 1920-3041. A iniciativa

39 Em depoimento para vídeo produzido por Nicholas Dieter Rauschenberg em 2011 pelo Programa Petrobrás Cultural. Disponível no youtube em: http://www. youtube.com/watch?v=ew5e2_8PeBs e http://www.youtube.com/watch?v=Dip_ EaOGsTM\&feature=email. Nicholas também dirigiu o documentário (Des) encontros no Tradicionalismo Caipira (2009) vencedor do Prêmio DOC TV. Acessos em: 25 jan. 2013 .

40 Dicionário Cravo Albin de Música Brasileira. Edição online. Pedro Chiquito. Página disponível em: http://www.dicionariompb.com.br/pedro-chiquito/biografia Acesso em: 13 mar. 2013. Dicionário Cravo Albin de Música Brasileira. Edição online. Nhô Serra. Página disponível em: http://www.dicionariompb.com.br/nho-serra. Acesso em: 13 mar. 2013 .

41 OLIVEIRA, Allan de Paula. O Tronco da Roseira: uma antropologia da viola caipira, 2004, 178f. Dissertação (Mestrado em Antropologia Social) - Centro de Filosofia e 
resultou na criação da "Turma Caipira Cornélio Pires" que posteriormente foi seguida pela "Turma Caipira Victor", cujo material foi lançado seis meses após a produção de Pires. Ao contrário de Pires que gravou na capital, a turma da Victor realizou as gravações em Piracicaba.

Em paralelo, Cornélio Pires organizou vários shows com a participação de cururueiros em São Paulo e outras cidades, com destaque para a apresentação do Colégio Mackenzie na capital. Pires também coordenou o cururu na rádio Educadora Paulista em 1936. Em 1910, alguns cantadores se reuniram em palco montado na cidade de Tietê. Foi o primeiro espetáculo do gênero. No entanto, o primeiro disco de cururu propriamente só foi gravado em 1959 pelo selo Sertanejo da gravadora Chantecler. O disco Cururu de Piracicaba foi gravado por Nhô Serra de um lado e Pedro Chiquito do outro. Tangendo a viola estavam Manezinho e Nenê. Narciso Correia e Zico Moreira gravam na sequência, ainda em 78 rpm. A difusão do vinil (LP) favorece a gravação de outros cantadores como Parafuso, Luizinho Rosa, Horácio Neto, Dito Silva, Silvio Pais, Nhô Chico e Jonata Neto ${ }^{42}$.

\section{São velhas agonias, novas tecnologias}

Durante os anos 1950 e 1960, estar no mercado musical através da forma disco era quase obrigatório. Estabelecer vínculos com uma gravadora para a projeção do trabalho junto a grandes públicos tinha mais força do que tem hoje. À época dos quatro bambas, a gravação de um disco era a situação por excelência para difundir o cururu. $\mathrm{O}$ disco era tido como oportunidade que reforçava o prestígio do cururueiro, alimentando a lógica que rege o cururu paulista. Daí que disco e rádio tornaram-se forma de ser apropriado e se apropriar do desenvolvimento da indústria fonográfica e dos meios de comunicação em São Paulo.

Liderados pelo ‘empreendedorismo' de Nhô Serra (1928-1997), os bambas articularam certa "ascensão" social e política no contexto dos integrantes. Essa oportunidade pessoal foi maior tanto em função do desenvolvimento industrial e surgimento de novos suportes de gravação e outras formas de produção, quanto à medida em que o grupo caipira ${ }^{43}$

Ciências Humanas, Universidade Federal de Santa Catarina, 2004; SANTA ROSA, Sérgio. Prosa de Cantador: a história e as histórias dos cururueiros paulistas. SANTA ROSA, Sérgio. Prosa de Cantador: a história e as histórias dos cururueiros paulistas, p. 19 .

43 Usamos a expressão "grupo" ou "grupos caipiras" entendendo que não se pode situar a condição identitária e sociocultural caipira limitada apenas ao espaço que 
se apropriou das tecnologias em voga para incrementar sua prática e mantê-la viva.

Para se ter uma ideia do alcance mobilizador de Nhô Serra e do cururu, já nos anos 1970:

O cururu era o seguinte: nós trabalhamos em Piracicaba em 1970 e no ano de 1970 nós conhecemos o Nhô Serra. Ele trabalhava no nosso circo, fazia o show de cururueiros. Então nessa época, era a maior casa, a gente podia ir onde for em São Paulo, não dava tanto dinheiro como trazer o cururu no circo. Era o maior show, todo mundo ia. Porque eles faziam assim, contratavam um desafio, era um desafio, ai vinha o Nhô Serra, o Parafuso, o Dandá (nós adorava ele), eles vinham e traziam outros cururueiros que eram de Itu pra fazer a contrapartida. ${ }^{44}$

Havia eficiência na articulação entre o circo, o rádio, o cururu, a música sertaneja e a propaganda. O cururu era tão importante para o circo que Sônia Gray, como proprietária do Disparada, afirma que eram os circenses quem buscavam o apoio e a presença dos cururueiros nas noites de espetáculo. Ainda que tivessem de dividir o faturamento da noite a presença dos cantadores era garantia de casa cheia e o rateio compensava para o circo. Outra vantagem era que, por causa do cururu, durante as transmissões do rádio havia uma divulgação gratuita do circo. O radialista, ao promover a apresentação do cururu, divulgava não apenas quais seriam os cururueiros presentes, mas fazia uma propaganda indireta da localização do circo e das atrações que o compunham:

O circo ia atrás dos cururueiros, pelo menos no nosso era assim. Porque eles faziam no nosso (Circo Disparada) e fazia no Circo Veneno, lá em Piracicaba. Eles faziam na região onde tivesse [circo]. Eu gostava que eles iam no circo porque além deles dar casa, eles anunciava todo dia, eles anunciava no Programa do Nhô

compreende o estado de São Paulo ou ao Médio Tietê que estudamos, visto que o que se conhece por cultura caipira permeia outros estados brasileiros como Goiás e Minas Gerais, por exemplo.

44 Sônia Gray em depoimento a 02 de junho de 2008. Sônia é mãe de Joelma de Jesus da Costa, pesquisadora do universo circense brasileiro e fundadora da ASFACI, Associação de Famílias e Artistas Circenses. Sônia e Joelma contribuíram para o documentário O Canto da Lona (Thiago Brandimarte Mendonça (p/b, 25 min, SP, 2013). 
Serra: "Tal dia nós vamos tar no circo Disparada que tá armado em tal lugar", quer dizer: todo mundo ficava sabendo onde é que tava o circo! $!^{45}$

Se por um lado o rádio era um bom meio para difundir a voz e a sonoridade dos cururueiros, por outro o circo era o espaço perfeito para ser visto e reconhecido pessoalmente pela plateia dos improvisos. Este tipo de mobilização que Nhô Serra encabeçava na articulação entre programas de rádio e apresentações em circos na região resultou na exposição destes artistas locais aos mais diferentes públicos através de shows, programas de rádios, propagandas eleitorais e solenidades.

Nhô Serra começou como cantador em fins dos anos 1940 depois que migrou para a cidade de Piracicaba e passou a comandar programas de cururu e música sertaneja em diversas rádios no Médio Tietê por décadas. Segundo aponta seu filho Oscar Francisco Silva Bueno, Serra trabalhou na Difusora de Piracicaba (PRD-6), na PRF-8 em Botucatu, Rádio Convenção de Itu, Rádio Cacique em Sorocaba, na Rádio Globo em rede nacional e em Capivari fazia programas ao vivo e gravados que iam ao ar aos sábados e domingos.

Dinâmicas como essas tiveram desdobramentos que resultaram em oportunidades para a gravação de discos de cururu-canção ${ }^{46}$. No processo conduzido pelos cururueiros enquanto prática tradicional, sem perder de vista as tendências sonoras e técnicas de seu tempo histórico, é que se incrementa o modo de fazer cururu que resulta na forma canção.

A gravação sonora em disco para fins comerciais, ainda que não tenha contemplado a maioria dos cantadores e violeiros, nunca foi a finalidade principal da produção cururueira. Tal como o era o circo e o rádio, o disco passa a ser uma nova forma de difusão do cururu que nunca superou as transmissões sonoras de rádio - sem o disco, as captações em áudio dos cururus presenciais eram reproduzidas nos estúdios radiofônicos ou ainda gravadas no próprio estúdio das rádios em cidades da região, sobretudo as mais urbanizadas da época como Piracicaba.

$\mathrm{Na}$ atualidade, essa dinâmica está mais viva do que nunca. Cururueiros como Cido Garoto tiram máximo proveito da ampla gama de relações que possuem com cantadores e violeiros de todo o Médio Tietê e

45 Sônia Gray em depoimento cedido à pesquisadora em 02 de junho de 2008.

46 Para Mário de Andrade (1930), os discos são "documentação rigidamente etnográfica” como expressou no artigo "Gravação Nacional” em Taxi e crônicas no Diário Nacional. Estabelecimento de texto, introdução e notas de Telê Ancona Lopes. São Paulo: Duas Cidades/SCCT, 1976 (pp. 296-7), crônica de 10 de agosto de 1930. 
tem largo conhecimento não apenas para fazer o cururu no improviso e nos desafios, mas também para conduzir a logística necessária para que as rodas existam como acontecimento efetivo, bem como para difundir o cururu junto a outros públicos como os que circulam em unidades do Sesc por exemplo. Cido transita constantemente com sua perua kombi ${ }^{47}$ seja para participar das rodas, seja como acompanhante ou motorista de cururueiros que vão se apresentar fora de Sorocaba, seja como distribuidor de CDs e DVDs que ele mesmo reproduz e repassa a preços de custo de produção. Do ponto de vista da produção sonora voltada para o mercado fonográfico, as gravações em disco consolidam o cururu como um gênero de moda de viola caipira "no estilo das duplas". ${ }^{48}$ Essa formatação do tempo do improviso à lógica do relógio e ao espaço da faixa no formato rpm ou vinil significou a incorporação do cururu como ritmo do meio rural à indústria fonográfica. No entanto, e como já observamos, a canção como realização no meio cururueiro, embora tenha sido paralela a este processo, independe dele.

Uma boa mostra dessa relação pode ser entendida no relato do cururueiro Manezinho Moreira. O cronista do mundo rural e da periferia urbana de cidades no interior de São Paulo conta que várias composições de sua autoria foram cedidas a outras duplas. Algumas dessas composições, Manezinho fez questão de cantar para que ouvíssemos pois as tem gravadas na memória. Embora muitas delas não tenham sido gravadas por ele o relato de Manezinho denota faceta velada, mas frequente do trânsito entre violeiros e cururueiros com nomes da música sertaneja voltada para o mercado consumidor. Essa faceta de apropriação das canções de grupos empobrecidos é mais reconhecida pela historiografia sobre o samba, relativa a grupos negros moradores de favelas no Rio de Janeiro. Realizadas por cancionistas do morro, essas canções tem a autoria contestada ou resultaram em gravações registradas por compositores do "asfalto" carioca.

O relato de Manezinho é dotado de atitude reivindicatória muito consciente das dimensões de disputa em torno da produção cultural no meio cururueiro e sertanejo. $\mathrm{O}$ alcance de suas canções atesta a criatividade que dá prestígio ao artista popular, ainda que não tenha sido ele quem efetivamente possua os direitos autorais sobre a música. Para

47 Apontamentos audiovisuais acerca de circulação e movimento no cururu no Médio Tietê podem ser vistos de dentro da perua Kombi de Cido através do olhar de Nicholas Dieter Rauschenberg em vídeo produzido em 2011 através do Programa Petrobrás Cultural. Disponível no youtube em: http://www.youtube. com/watch?v=Dip_EaOGsTM\&feature=email. Acesso em: 23 ago. 2013.

48 CORRÊA, Roberto. A Arte de Pontear Viola. Brasília, Curitiba: Ed. Autor, 2000. 
ele, que narra sua experiência de vida como cancionista e cronista ficam nulas as distinções de forma estética entre música sertaneja e cururu: o que ele faz são canções. Possuindo criações em ambos os estilos musicais e atuando como cantador e violeiro, seu relato é desprovido de distinção hierárquica. Manezinho forjou uma identidade artística transitando pelas duas formações musicais: o cururu e a música sertaneja seja como cantador, seja como violeiro.

Por outro lado, a configuração do cururu como música de amplo alcance no mercado fonográfico pode ser vista em " $O$ menino da porteira" de Teddy Vieira ${ }^{49}$ (1922-1965) e Luizinho (Luis Raimundo, 1916-1983) consagrada nas vozes de Tonico e Tinoco em 1956. Em 1973 a canção foi gravada por Sérgio Reis marcando a trilha sonora do filme homônimo (1977) estrelado pelo cantor. O ritmo do cururu acompanha versos que contam a história do menino que morreu vítima de "um boi sem coração" e foi intensamente regravado. Com o remake do filme homônimo em 2009, a canção tomou nova forma na voz e protagonismo do cantor sertanejo-romântico Daniel conhecido da dupla João Paulo e Daniel. No entanto, a primeira gravação da canção é de 1955 por Luizinho \& Limeira.

Essa dimensão do cururu como produto acabado com fins de consumo, tal como n' "O Menino da Porteira”, estabeleceu diálogo importante com o cinema nacional retomando o universo caipira nos filmes de Mazzaropi nos anos $1960^{50}$. As gravações em disco impuseram outra

49 Teddy Vieira de Azevedo (1922-1965) nasceu em Itapetininga, no Médio Tietê. Além de "O Menino da Porteira” é também compositor de outras músicas importantes e afamadas no universo caipira-sertanejo brasileiro: "Couro de Boi" (1954) em coautoria com Palmeira (Diego Mulero, 1918-1967), "João de Barro" (1956) em parceria com Muibo Curi) e "Pagode em Brasília” em 1959 em parceria com Lourival dos Santos. Tonico e Tinoco e Sérgio Reis também gravaram "João de Barro" e "Pagode em Brasília" é muito conhecida nas vozes da dupla "Tião Carreiro e Pardinho". Dicionário Cravo-Albin da Música Popular Brasileira. Página disponível em: http:// www.dicionariompb.com.br/teddy-vieira/obra. Acesso em: 17 abr. 201z. RIBEIRO, José Hamilton. Música Caipira: as 270 maiores modas de todos os tempos. São Paulo: Globo, 2006.

50 É o que se pode notar na canção "Tristeza do Jeca” que inspirou o filme homônimo (1961) de Mazzaropi. O título da canção já destaca a vinheta de abertura da música homônima ao filme. Em momentos importantes da história a narrativa é entrecortada pela canção em fundo instrumental na tentativa de expressar o tema. LOBATO, José Bento Monteiro. Idéias de Jeca Tatu. São Paulo: Brasiliense, 1946; Cidades Mortas. São Paulo: Brasiliense, 1959; Urupês. São Paulo: Brasiliense, 1991. "Tristeza do Jeca" (1918) composição de Angelino de Oliveira foi apresentada em saraus pelo próprio autor em 1918 ainda sem letra, depois em 1924 pela Orquestra Brasil-América. Foi somente em 1926 gravada com letra pelo cantor Patrício Teixeira. RIBEIRO, José Hamilton. Música Caipira: as 270 maiores modas de todos 
temporalidade e forçaram adaptações aos cururueiros. A forma acabada da canção impõe o tempo limite concebido comercialmente, com dois ou três minutos por faixa e restringiu o livre improviso de cantadores e violeiros. Outra mudança importante foi a intensificação do cururu como desafio e menor ocorrência das louvações e temas religiosos nas gravações $^{51}$.

Fomentando a lógica de registro e de difusão do cururu, as gravações em CDs e DVDs são difundidas e comercializadas no Médio Tietê. Antecipando certa tendência da produção musical contemporânea, inclusive da cena hip hop, as produções no cururu são realizadas de maneira independente e vendidas nos locais em que acontecem as apresentações. A prática consiste em comercializar os discos após o término das apresentações presenciais e Cido Garoto é grande veiculador neste sentido. Os preços devem ser acessíveis aos trabalhadores e suas famílias, mas suficientes para cobrir os custos de produção do material. Resulta mais numa forma de difundir o cururu do que uma fonte de renda para quem os vende, embora não exclua essa possibilidade. De toda forma, o cururu é limitado ao consumo dos apreciadores. Sua peculiaridade enquanto canção tradicional o vincula à zona cururueira ou a colecionadores, especialistas e estudiosos.

A exemplo do que faziam Cornélio Pires desde 1910 e Sebastião da Silva Bueno (o Nhô Serra) empresariando 52 "Os Quatro Bambas" nos anos 1940 a 1970, cantadores como Moacir Siqueira em Piracicaba acabam por direcionar o formato de shows onde o cururu se mescla às apresentações de duplas sertanejas ${ }^{53}$. Moacir é radialista e já foi candi-

os tempos. Além de Tonico e Tinoco (1958), Sergio Reis, Chitaozinho \& Xororó e Zezé di Camargo \& Luciano, entre outros, fizeram regravações da música.

SANTA ROSA, Sérgio. Prosa de Cantador: a história e as histórias dos cururueiros paulistas.

52 Embora Nhô Serra atuasse mesmo como empresário, o depoimento de seu filho aponta que Serra não teria sido o fundador dos quatro bambas. O grupo já existia em fins dos anos 1940 e era muito fechado entre si, delimitando o cururu da região à sua atuação. Esta última afirmação é confirmada por Cido Garoto em depoimento já referido.

53 Oscar Francisco Silva Bueno, o Serrinha, conta que o pai teria impulsionado as trajetórias de Jonata Neto e do próprio Moacir Siqueira: antes conhecido por Moacir 7o. Disponível em: http://memorial-piracicaba.blogspot.pt/20o8/12/sebastioda-silva-bueno-nh-serra.html Acesso em: 12 mar. 2013. Nhá Bentinha, enquanto apresentadora dos desafios - uma das principais atividades da artista circense, radialista e cantora sertaneja - lança mão de várias duplas que vão aos desafios com o propósito de aproveitar a oportunidade de ser vista ao vivo pelas plateias de cururu. Essa visibilidade é vantajosa para as duplas recém-lançadas por projetar suas carreiras em âmbito local. As duplas sertanejas preenchem os intervalos de apresentação dos cururueiros, bem como divertem e evitam a dispersão do 
dato a vereador por Piracicaba. É muito conhecido no meio não apenas enquanto cantador de cururu, mas pelo grande intercâmbio que realiza conduzindo trabalhos de cantadores, violeiros e duplas sertanejas da região. Este mesmo trabalho é realizado em Sorocaba e Votorantim na liderança da apresentadora de cururus e cantora sertaneja Nhá Bentinha.

Bentinha fomenta a produção de novos trabalhos e promove um direcionamento do consumo musical. Iniciativas mobilizadoras da produção cultural local nesses moldes não são exclusividade da estratégia caipira no Médio Tietê. Elas acontecem em diversos pontos do país.

Essa forma de "vender o próprio peixe" e de coordenar todas as etapas do trabalho artístico após o desmonte da indústria fonográfica tem sido a estratégia adotada por vários artistas contemporâneos. Gaby Amarantos que se autodeclara ${ }^{54}$ representante da música contemporânea produzida no estado do Pará era responsável por todas as etapas do processo artístico desde a produção, divulgação e circulação do trabalho gravado de forma caseira. Levava pessoalmente as gravações aos $d j s$ paraenses, aos produtores de festas e camelôs espalhados por Belém, para além do bairro Jurunas situado na "periferia" paraense.

$\mathrm{Na}$ capital paulista especialmente, onde por certo tempo essa tendência parecia estar mais centrada na linguagem do hip-hop e do rap, a prática está amplamente difundida e realmente consolidada, marcando a geração atual de artistas independentes e das mais diversas propostas musicais.

Na segunda metade do século XX, as transmissões de rádio teriam sido as principais responsáveis pelo incremento da difusão comercial desses temas com papel paralelo ao que hoje tem a internet. À época,

público quando há atrasos ou furos na programação, o que é relevante para quem apresenta o show da noite. É inclusive momento para a dança, pois o cururu exige mais a audição e a visão, dentre todos os sentidos da plateia.

54. Gaby Amarantos é conhecida por articular os gêneros musicais tradicionais paraenses como o carimbó com outras influências como o zook e o brega. Outra especificidade é que a internet foi seu principal veículo de difusão. O videoclip "Xirley", que contou com direção e roteiro de Priscilla Brasil e produção da Greenvision em 2011, é autobiográfico: a cantora protagoniza Xirley Xarque para ilustrar sua própria trajetória rumo ao estrelato. É também exemplar da forma de produzir, protagonizar, divulgar e fazer circular o trabalho pelo próprio artista e chama a atenção para o que tem sido considerado como pirataria ou "música de bandido". Entrevista à Revista Rolling Stones em 12/11/2012. Disponível em: http:// rollingstone.com.br/noticia/nando-reis-e-gaby-amarantos-falam-sobre-duelomusical-em-belem/. Entrevista à jornalista Marília Gabriela para o Programa De frente com Gaby exibido em 15/01/2012 no SBT. Disponível em: https://www. youtube.com/watch?v=NvovmGWC2Qc e https://www.youtube.com/watch?v=_ Evfdza55e8. Acessos em: 20 mar. 2013. 
o rádio pode ser considerado veículo de comunicação mais "democrático" quando comparado ao disco em $78 \mathrm{rpm}$ ou ao vinil (LP), pois a difusão musical por via radiofônica é mais ampliada e acessível em meios urbanos e rurais. Como objeto de consumo cultural surgido com o desenvolvimento de uma indústria específica, o disco era bem menos acessível aos grupos cururueiros - tanto para gravar suas composições ${ }^{55}$ como para o consumo das canções. Esse fator fica mais explícito se hoje compararmos o LP ao formato CD e DVD tão difundidos em virtude de sua ampla reprodutibilidade e da ampliação dos meios de gravação e reprodução em âmbito doméstico.

No meio cururueiro, para além dos encontros presenciais de cururu, o rádio ainda hoje é o maior veículo irradiador de uma dada canção ou álbum sonoro. Um radialista é o agente divulgador de produtos culturais sonoros. O radialista ou apresentador de programas ou mesmo o apresentador de shows de cururu faz da canção instrumento de execução coletiva, capacidade restrita no disco de execução musical privada e voltada ao consumo mais individualizado. O rádio constitui meio indireto de consumir as canções e os discos, mas tem a vantagem de promover a canção - ainda que tal acesso seja mediado por um agente que seleciona o que se ouve. A mediação da escuta e projeção das canções também marca as trajetórias de Moacir Siqueira e Nhá Bentinha no âmbito cururueiro/sertanejo.

\section{Reforma agrária da música brasileira ${ }^{56}$}

Narrativa sonora em constante transformação no tempo e no espaço do Médio Tietê, o cururu é forma coletiva que produz e transmite saberes através da oralidade e do ritmo. Remonta a diferentes contextos históricos, desde o processo de ocupação das terras paulistas em fins de século XVII passando pelas transformações do mundo rural até o contexto atual com apropriações das inovações tecnológicas e meios

55 Há aqui outro ponto em comum do cururu com a música produzida nas favelas cariocas. O papel dos Quatro Bambas ou de Chiquito e Serra, como porta-vozes do mundo caipira no contexto fonográfico brasileiro atesta as escassas oportunidades de gravar um disco pela maior parte dos compositores tradicionais de diferentes gêneros. Em meio a contextos culturais reprodutores da desigualdade cognitiva e social, a figura representativa dos Quatro Bambas na zona cururueira e de nomes como Bezerra da Silva no âmbito carioca adquirem dimensão ainda maior para compreensão da canção brasileira nos âmbitos estético, social e produtivo.

56 Verso da faixa "Samba do Fim do Mundo" de "O glorioso retorno de quem nunca esteve aqui". 
comunicacionais, tais como o rádio e o disco - a partir de 1940 para um e 1950 para o outro. Tais processos continuam em intensidade favorecidos pela internet e redes sociais, o audiovisual e produção de CDs, publicações impressas e DVDs independentes. Essas iniciativas se juntam às já articuladas relações do meio cururueiro com radialistas, festeiros do Divino, apresentadores, pequenos empresários, comerciantes, políticos locais e duplas sertanejas da região.

A apropriação dos suportes, técnicas e tendências já no início do século XX contribuiu para o incremento das relações internas de prestígio e reconhecimento social que motivam o cururu. Com a projeção do próprio cururu e de seus realizadores ocorreu alguma, ainda que restrita, inserção comercial no conjunto da produção musical de mercado.

$\mathrm{O}$ que se verifica acompanhando as dinâmicas desses processos históricos é que o cururu é prática poético-musical que consiste numa racionalidade singular de grupos caipiras do Médio Tietê paulista. Enquanto expressão cognitiva específica do grupo caipira está articulada à sua própria constituição identitária, permeando a reorganização das memórias e valores fundantes da cosmovisão caipira.

Mas à medida que são transformadas as relações sociais, culturais e políticas também essas narrativas são transformadas. O mesmo ocorre com as formas de condução e produção do cururu. Acompanhando tendências socioculturais e econômicas, a modalidade respondeu aos diferentes processos históricos, resistindo e incorporando mudanças em sua forma estética ${ }^{57}$. O que permanece é a forma rítmica e melódica conduzida pela viola. Desta maneira, o cururu tornou-se um tipo muito específico de canção popular ${ }^{58}$.

Cantadores, violeiros, pequenos empresários e comerciantes, radialistas, artistas circenses enquanto articuladores da produção cultural paulista - seja em âmbito local ou nacional - estão empenhados na luta cultural e por fazer valer seus próprios discursos, linguagens e expressões artísticas. A busca por reconhecimento não se dá apenas em âmbito interno, em meio ao grupo de pertencimento identitário, sendo

57 IKEDA, Alberto T. Cururu: resistência e adaptação de uma modalidade musical da cultura tradicional paulista.

$5^{8}$ A presença da viola caipira no cururu é insuperável e marca seu caráter de repente. Dentre os instrumentos que podem acompanhá-la durante as cantorias estão o acordeão, o pandeiro (muito comum), o reco-reco, ou mesmo outra viola ou violão. Também houve casos em que o som percussivo era retirado do bater de duas colheres em atrito ao corpo (perna ou coxa) do instrumentista. Quando da presença de violeiros muito jovens, pode haver acompanhamento da viola em parceria com o baixo elétrico como observamos em Piracicaba (2010) e Votorantim (2011). 
importante o prestígio atribuído por outros setores da sociedade. A gravação em disco e a forma cururu-canção como crônicas do cotidiano são materializações expressivas destes objetivos.

Dedicados às plateias ou assistências os cururueiros objetivam audiência. Essa luta por reconhecimento permeou shows e mobilizações do meio cururueiro durante os anos 1920-70 em forte relação com o desenvolvimento da indústria fonográfica contribuindo para a reprodução histórica do cururu como estética. Cantadores e violeiros protagonizavam ações conscientes, buscando tornar proveitosas suas relações pessoais para ampliar intervenções dos grupos caipiras em outros contextos.

Do ponto de vista global, esses processos resultaram no cururu como legado tradicional e influência importante para a canção brasileira, sobretudo para aquela que se faz em São Paulo. A larga influência que a dimensão social possui na canção feita no país constitui importante exemplo da força que modalidades musicais tradicionais como o cururu possuem na produção cultural contemporânea.

Os temas, práticas e angústias caipiras compõem crônicas sobre a vida urbana paulista na música urbana de ontem e hoje. As narrativas dos causos caipiras ${ }^{59}$ e a sonoridade provocada pelas cordas da viola fundam no século XX com Cornélio Pires - passando por Mazzaropi -uma "tradição" de cronistas da vida paulista que está articulada às produções de outros cronistas-musicais da/na Pauliceia contemporânea e que se desdobram na releitura do dialeto e sonoridades caipiras na cidade de São Paulo ${ }^{60}$.

Sabemos que a tradição visibilizada por Cornélio Pires no início do século XX provém das expressões de arte coletiva de grupos cururueiros ${ }^{61}$ e estão profundamente enraizadas na religiosidade popular devocional.

59 PIRES, Cornélio. Meu Samburá: anedotas e caipiradas. São Paulo: Amadio, s/d; Conversas ao pé do fogo: páginas regionais. São Paulo: 1927.

6o No Rio de Janeiro, o migrante pernambucano Bezerra da Silva cantava "Na verdade eu sou um cronista/que transmito o dia a dia do meu povo sofredor/Dizem que gravo música de baixo nível/ porque falo a verdade que ninguém falou": Partideiro sem nó na garganta (Adelzonilton, Franco Teixeira e Nilo Dias) gravada no álbum Presidente Caô Caố, BMG Ariola, 1992.

61 Resulta que a tradição empenhada por Cornélio Pires situa-se na vivência e permanência do cururu tão ao gosto dos grupos caipiras. GALANTE, Rafael. De Cornélio Pires a Kiko Dinucci: a vocação cronística da música de São Paulo. Artigo reproduzido no post "Quase tudo o que eu queria ter dito do Dinucci e não consegui...” do blog Circus Produções. Disponível em: http://www.circusproducoes. com.br/blog/?p=1506. Acesso em: 12 out. 2012. 
Resulta então que a música da São Paulo contemporânea ${ }^{62}$ propõe uma síntese que é também caipira. Foi este sentido da crônica cancional, que tentamos alcançar com os paralelos realizados aqui, aproximando o universo do cururu com a linguagem do rap.

Com a retomada e influência da linguagem e das narrativas tradicionais populares ${ }^{63}$ houve certo deslocamento do eixo centro-periferia/capital-interior que implica noutra geografia proposta pelo som e pela voz. Para além dos já citados, dois bons exemplos de registros que retomam o universo popular tradicional estão no elogiado álbum de estreia da rapper curitibana Karol Conká, Batuk Freak (Nave Beats, 2013). A última faixa "Caxambu" (Bidubi, Jorge Neguinho, Zé Lobo e Élcio do Pagode) remete ao universo jongueiro já trazido por Almir Guineto (RGE) em disco de 1986 repleto de parcerias. Enquanto que a faixa "Vô Lá" está o tempo todo permeada de samplers de rimas de coco (percussão de pandeiro, citações e versos) quase à revelia da batida dançante e para compor com ela uma sintonia rasurada, ao passo que as rimas da rapper somam-se para imprimir o caráter "embolado" da faixa. Há ainda outras passagens e faixas que remetem à música tradicional devocional no disco da rapper.

Esses densos processos trazem necessariamente a emergência de novas relações que redirecionam os rótulos "tradicional" e "moderno", atestando tanto a modernidade das práticas do catolicismo popular enquanto tradição constantemente re-inventada (e que alimenta a cena urbana-industrial ou alternativa e/ou de autoria) quanto da produção musical atual como tradição - com continuidade na linha das crônicas urbanas à la Cornélio Pires, Adoniran Barbosa, Paulo Vanzolini entre outros $^{64}$.

Após as reflexões e apontamentos realizados aqui, podemos inferir nas letras dessas canções que a noção conceitual-poética atua como

62 Aqui especificamente referida aos trabalhos de compositores/músicos/produtores paulistas como Kiko Dinucci, Juçara Marçal e Thiago França em Metá-Metá (2011) e ao primeiro álbum de Rodrigo Campos intitulado São Mateus não é um lugar assim tão longe (2009). As parcerias constantes entre esses artistas implicam uma ressignificação importante do mutirão como forma de produção musical marcante da canção contemporânea. A título de curiosidade e como metáfora do acaso: Rodrigo Campos é natural de Conchas, cidade da zona cururueira, mas se mudou ainda com três anos de idade para São Mateus na "periferia" de São Paulo. Disponível em: http://www.amusicoteca.com.br/?p=zogo. Acesso em: 26 fev. 2013.

63 CANCLINI, Néstor-García. As Culturas Populares no Capitalismo. São Paulo: Brasiliense, 1983. 149p. MARTÍN-BARBERO, Jesús. Dos Meios às Mediações: comunicação, cultura e hegemonia. Rio de Janeiro: UFRJ, 2013. 356p.

64. GALANTE, Rafael. De Cornélio Pires a Kiko Dinucci. 
uma espécie de alegoria do popular, um jeito de inserir temas da religiosidade, do cotidiano, do trabalho assalariado, do lazer, dos conflitos étnico-raciais e de classe social: o percurso que se faz de casa ao trabalho no busão ou no trem, as contas para pagar ao fim do mês ou mesmo a ausência do emprego como estatuto e a dificuldade de encontrá-lo; as práticas de sociabilidade e de lazer (as festas religiosas, as quermesses, o futebol de "várzea", os parques de diversões, a vivência nos bares, os encontros fortuitos em espaços considerados marginais da cidade, as feiras e mercados populares) estão mais vivos do que nunca na canção popular.

O cururu como contributo da produção na canção é fato, mas o debate não pode ser conduzido sem atentar para o protagonismo dos cururueiros como sujeitos que influenciaram diretamente na constituição da indústria cultural do país. Apenas para falar no alcance histórico que os cantadores e contadores de causos possuem para produzir e transmitir saberes, basta dizer que práticas como o cururu são realizadas por sujeitos articuladores, mediadores e difusores inseridos ou não nos circuitos industriais. $\mathrm{O}$ fato é que suas práticas inspiram diferentes cenas musicais até hoje.

Cientes de seus legados, fazedores da canção dita tradicional no cururu paulista, os cantadores têm ampliado sua atuação de intelectuais internos para continuar forjando discursos próprios e para apresentá-los a outros setores da sociedade, ampliando os diálogos iniciados por afamados do cururu das antigas à revelia de noções que ainda enxergam no "tradicional" algo que "está para acabar". Assim, quando o mundo tradicional acabar para dar início ao mundo moderno, o que restará será um samba com jeito de maracatu ${ }^{65}$.

65 Que é como o cronista rapper resiste ao fim do mundo em O Glorioso Retorno de Quem Nunca Esteve Aqui. 


\section{Sobre a autora}

\section{Elisângela de Jesus Santos}

Professora da área de Cultura e Sociedade no Bacharelado em Línguas Estrangeiras Aplicadas às Negociações Internacionais (LEANI) e no Programa de Pós-Graduação em Relações Étnico-Raciais (PPRER) do CEFET Rio de Janeiro, campus Maracanã. Investigadora em Pós-Doutoramento no Centro de Estudos Sociais da Universidade de Coimbra. Bolsista Capes de Estágio Pós-Doutoral no Exterior entre fevereiro e agosto de 2014. Pesquisadora associada ao Centro das Culturas e Línguas Africanas e da Diáspora Negra (CLADIN) e ao Laboratório de Estudos Africanos, Afro-Brasileiros e da Diversidade (LEAD) e ao Grupo de Estudos Culturais da UNESP Franca. Integrante da Rede de Reflexão e Ação Étnico-Racial (RRAE). Coordenadora do Catavento: grupo de estudos e pesquisas para as culturas populares. Por vezes usa a voz como instrumento sonoro. E-mail: lili.libelula@gmail.com

Agradecimentos: a todos os cururueiros que margeiam o Tietê e que colocaram palavras na minha tinta, sou muito grata, e em especial ao Cido Garoto, Nhá Bentinha, Batista Neves, Manezinho Moreira, Moacir Siqueira e ao radialista João Carlos Martinez. A Daniel Teixeira Júnior, cuja sonoridade harmônica em tons blues acompanhou este texto nas tardes do Mondego. Agradeço ainda a Joelma Costa e Sônia Gray. A Fábio Gerônimo e André Machado, pela dedicação na transformação do dialeto de-repente-pra-outra-língua. Ao professor Alberto Ikeda, pela tarimba que tomei de empréstimo. Agradeço ainda a Carol Aguerri e Adilson Gennari, Isabela Morais, Bruna Muriel, Leandro Oliveira, Jayça Sant'Ana e Davi Bovolenta. Os resultados de pesquisa organizados neste artigo receberam apoio e financiamento da Fapesp durante meus trabalhos de mestrado (2006-2008) e doutorado (2009-2013). 
